\title{
Russian perceptions of the Boer and British Armies: An introduction through Russian documents
}

\author{
DR GENNADY SHUBIN \\ Institute for African Studies, Moscow
}

On the eve of the outbreak of the Anglo-Boer War in South Africa, Colonel N.S. Yermolov, the Russian Military agent [attaché] in London reported on October 1, 1899: ${ }^{1}$

"The War is inevitable... The decision has been made to dispatch there from Britain the first army corps and at least 70 thousand [troops]...

The War is scheduled for half a year; many mounted infantry are under preparation; carts and mules being purchased in America. The general draft disposition is to defend the border of Natal, [and] offensive from PortElizabeth towards Bloemfontein and Pretoria."2

For days later, on 5 October 1899 (all the dates are according to the "new", that is European calendar) he sent another coded message to General Sollogub, the Head of the Military Studies Committee (Voyenny Ucheny Komitet) ${ }^{3}$ of the General Staff: "The War has started. The Boers crossed the borders." The War Minister Kuropatkin wrote on it the following instruction: "Since Britain recognised the Transvaal as a warring side it is necessary to send our Military Agent to Boers without delay."

Colonel Yermolov's message (or the date on it) was wrong: the war began only on 11 October. Two days earlier, however, on 9 October 1899 the Russian War Minister instructed the Chief of the General Staff to appoint immediately two officers of the General Staff to be present, one on each side, in the case of war in South Africa. ${ }^{5}$

Archive documents show that the actions had been taken immediately and even beforehand. On the same day the following instructions were sent:

Nikolai Sergeevich Yermolov (1853-1910(?) - Colonel, the Russian military agent [attaché] in London from 1891 to 1905, later Lieutenant General.

Donesenia voennogo agenta v Londone Generalnogo shtaba polkovnika Yermolova III, ot.1 oktyabrya 1899 goda. [in Russian] [Dispatches of the Russian military agent in London Colonel of General Staff Yermolov, III, 1 October 1899]. St-Petersburg, 1900, p.11.

The Military Studies Committee was engaged in several affairs, including Military Intelligence

4 Russian State Archive of Military History (RGVIA) Fund 488. file N 1448. document N 35 .

5 Foreign Policy Archive of Russian Empire (AVPRI) Fund 488. file 1451. document N 35 . 
"Office of the Military Studies Committee of the General Staff 9 October 1899 N 1434.

To Junior Desk Officer of the Office of the Military Studies Committee Lieutenant Colonel Stakhovich.

By the order of the War Minister, after receiving this [letter] you have to go to London when you have to wait for further orders for the trip to South Africa to observe the course of the operations between the troops of the Great Britain and the Transvaal Republic.

Lieutenant General Sakharov."

The plans to send a Military Agent to the Boer side, however, they encountered some difficulties. Count Lamsdorf, ${ }^{7}$ Russian Deputy Minister of Foreign Affairs on 7 October sent the following letter to the Deputy Head of the Military Studies Committee of the General Staff Lieutenant General Sakharov:

"Dear Sir. Victor Vassilyevich

In the letter of 6 October this year N 245 you deigned to Inform the Ministry of Foreign Affairs about Lieutenant General Kuropatkin's wish to send officer of our General Staff to the troops of the Transvaal Republic during the hostilities between the latter and the Great Britain. In consequence of it I have an honour to notify you that an official sending of a Russian officer to the mentioned country seems to be a rather delicate matter, because a highly important for the aggravation of the relations between the Great Britain and the Transvaal was an issue of the rights of the latter for independence, and therefore the position of the Republic, as a warring side, remained not yet ascertained..."

In spite of this 'smooth' language it was clear that the Russian Ministry of Foreign Affairs tried to avoid a diplomatic conflict with the country which 'ruled the waves' those days. However, the War Ministry continued preparations and after Britain officially announced that it was in a state of war with the 'South African Republics', the Russian Military agent with the Boer forces, Lieutenant-Colonel Romeiko-Gurko, was sent to Transvaal on 10 December, simultaneously with a Medical Unit of the Russian Red Cross. The permission of the Transvaal government was received by telegraph in advance.

Apart from Stakhovich and Romeiko-Gurko, three more Russian official military agents were sent to South Africa later - Captain Scheglov and Captain von Sigern-Korn (both - military engineers and both graduates of the Military Engineering Academy and later both colonels) to the Boer side and Captain Nicolai Mikhailovich Yolshin (later - Major General). Iolshin (who graduated from the Academy of General Staff too) was sent to the British side.

Shcheglov was the only official Foreign Military Agent who managed to observe both the Boers Army and the British Army (he was allowed to be there because the British military intelligence did not know about his stay in the Boers).

7

Ibid., document N I4.

Count Vladimir Nikolaevich Lamsdorf (1841-1907), the Deputy Russian Ministry of Foreign Affairs (1897-1900) and the Russian Ministry of Foreign Affairs (1900-1907) Ibid., document $\mathrm{N}$ I0. 
The official reports of all these three army officers were not published (though they are available in the archives).

In addition, several unofficial military agents went to the Boer Republics as "retired" officers. For example, Captain Alexei Stepanovich Potapov, the administrative secretary of the Russian Red Cross detachment (his report was published) and Lieutenant Alexei Yefimovich Yedrikhin, who took part in the siege of Ladysmith and observed the situation near the Tugela River. Both these junior officers before leaving their motherland to South Africa graduated from the Academy of the General Staff. In 1900 Yedrikhin published several analytical about the Anglo-Boer War in the Russian Liberal Daily Newspaper "Novoe Vremya" [New Time] under pen name van Damm.

\section{Potapov later was probably killed during the Russo-Japanese War.}

Yedrikhin also took part in the Russo-Japanese War, 1904-1905. However he several times temporally left the Army Service probably for secret mission as an unofficial observer in different countries. In 1907 'by His Majesty's (Nicholas the Second) highest decision' Yedrikhin changed his surname to van Damm (Vandam)! (Was this choice inspired by his trip in South Africa?). ${ }^{9}$

Perhaps we should say a few words about the attitude of the high Russian State authorities to those events ${ }^{10}$. In this sense the letter of Tsar Nicholas II to his sister Xenya ${ }^{11}$ about the first successful actions of the Boer's forces and the ability of Russia to completely destroy the British design is revealing:

"I am wholly taken by the war between Britain and Transvaal; every day I read through all the details published in the British newspapers from the first to the last line and then I share impressions with others at the table.

I can't help but express my joy about the yesterday's news, just confirmed that during the sortie of General White two British battalions and a mountain cannon battery were taken prisoners by the Boers!

They, as people say, flopped and [as a Russian proverb says] tried to cross the river not knowing where the ford was]. By this way the Boers reduced the garrison of Ladysmith from 10 thousand by the fifth part, having taken 2000 prisoners

It is not accidental that old man Kruger said, I believe, in his ultimatum to Britain, that before Transvaal perished, the Boers would surprise the whole world by their boldness and staunchness. His words are really coming to be true...

Later this officer took part in the First World War and raised to the rank of Major General. During the Civil War in Russia (1917-1922) he joined the White Army and was the Head of Staff of the Northern-West Front. After the White Army defeats he emigrated in Estonia and died there in 1935(?).

10 The war in South Africa started when the Russian-British rivalry in Central Asia and Persia made their relationship far from serene, eight years before Britain joined the Russian-French "Entente Cordial" when British turned from bitterest enemy to honourable ally of Russia.

11 Grand Duchess Xenia Alexandrovna (1875-1960). 
You lanom mottp://scientiamilitaria.journals.ac.za

You know, my dear, that I am not a proud person but I am pleased to think that the means to definitely change the course of the war in South Africa lies only in my hands. That means is very simple: to send by telegraph an order to mobilise the troops in Turkestan and approach the border [of Afghanistan]. That is all! No strongest fleets in the world would be able to prevent us there from dealing with Britain in her most vulnerable spot.

But the time has not come yet: we are not ready enough to undertake serious actions, mostly because Turkestan is not yet connected with inland Russia with uninterrupted railway. I have gone too far, however, but you'll understand that sometimes occasionally the well-wished dreams are rushing to the open and one can't contain himself but to share them.

Even here, in peaceful Darmstadt ${ }^{12}$ there is a great excitement, the same as elsewhere, against Britain and everyone takes an active part in the fate of the African Dutch.

When you receive this letter we'll have been already in Skernewits. On the way there we'll have to stay for almost a day at Potsdam, where I am going to hound the Emperor at the British in every possible way reminding him about his well-known telegram to President Kruger" ${ }^{13}$.

(However, the expression of enmity to Britain by Nicholas II did not prevent him, though much later, from being delighted with his promotion by King George $\mathrm{V}$ to the rank of Field Marshal of the British Army. In December of 1915 Tsar wrote to his wife the Empress Alexandra Fiodorovna:

"Fancy, Georgie has promoted me to Field Marshal of the British Army!"14

The rejoiced Empress answered: "How fine that you have been appointed a British Field Marshal.") ${ }^{15}$

There is one interesting circumstance: though the wife of the Russian tsar was German by origin, she was Queen Victoria's granddaughter as well and was brought up in Britain and supported that country vehemently at the time of the Anglo-Boer

Nicholas II wrote this letter in Germany, near Darmstadt, and was going to meet with German Emperor Wilhelm II.

Nikolai Romanov ob anglo-burskoi voine. [In Russian]. [Nicholas Romanov about the Anglo-Boer war] Krasnyi arkhiv. 1934. Vol. 2 (63). c.125-126. Quoted in: Rossiya i Africa. Documenty i Materialy XVIII v - 1960 g. Tom.1. ["Russia and Africa. Documents and materials. 18th century - 1960. Vol. 1]. Institut vseobschei istorii RAN. Moskva. 1999, p .153-154. The German political support to Transvaal during the Jameson Raid in 1895 was expressed in a telegram Kaiser sent to President Paul Kruger congratulating the Boers with the victory. That telegram aggravated the British-German relations.

The Letters of the Tsar to the Tsarina 1914-1915, London, New York, 1929, p.121. Quoted in: Rossiya i Africa. Documenty i Materialy, p.154.

Perepiska Nikolaya i Alexandra Romanovyh. Tom 3 [In Russian] [The correspondence between Nicholas and Alexandra Romanov, Vol. 3], Moscow Petrograd, 1923, p. 503-504. Quoted in: Rossiya i Africa. Documenty i Materialy, p.154. 
In order to prove it, I'll cite the following document dated April-June 1900 from the diary of General V.V. von Vaal: ${ }^{16}$

"About the pro-British attitude of the Empress Alexandra Fiodorovna during the Anglo-Boer War.

The Russian Imperial Family kept a private fund at the Bank of England, created by the Emperor Alexander the Second [ruled 1856-1881] during the troublesome time from 1869 to 1881 out of surplus money on the balance sheet of the Cabinet and [tsar's] Estates.

The sum accumulated there was as great as $\mathrm{L} 50 \mathrm{mln}$., i.e. $500 \mathrm{mln}$. roubles.

In the beginning of the war between Britain and the South African colonies the Empress Alexandra Fiodorovna, an ardent sympathiser of the British, ${ }^{17}$ persuaded the Sovereign to lend that money to Queen Victoria and the Sovereign agreed to do so not giving himself the account that this deed would encourage the plunderer's assault of a stronger one against a weaker in the evident contradiction to the principles, which had sponsored the convention of the Hague Peace Conference and decisions ensuing thereof.

Even less such a support given to Britain responded to the feelings all classes of the Russian people that ardently sympathised with the Boers and had all reasons to regard Britain as their bitterest enemy.

The best was done to keep that sad fact a secret of course it proved to be impossible because in Britain they did not conceal it, and the whole Europe came to know it.

The party of non-sympathisers to Russia is using this fact to explain the silence of Russia which, not long before the declaration of the unjust war stood as the apostle of peace, when Britain so brutally violated all the principles which had promoted the conviction of the Hague Peace Conference.

Von Vaal V.V. (1840-1915), Russian General, Deputy Minister of Internal Affairs in 1902-1904.

Alexandra Feodorovna (1866-1918), the Russian Empress, Nicholas II's wife. Very many in Russia hated her greatly for the serious influence exercised by her on her weak-willed husband, and because of her evident mental illness (this diagnosis was made by the leading Russian psychiatrists) and for her mysterious faith to fortunetellers and prophets (such as Grigory Rasputin and others) linked to her illness, as well as for permanent interference into state affairs which caused serious damage to the State. She was shot dead together with her husband, five children and servants by Bolsheviks in 1918.

The Hague Peace Conference convened on the request of Russia for the elaboration of multilateral agreements on the juridical rules of waging a war. 27 countries took part in this conference, including the Great Britain, USA, Germany, France, Italy, the Scandinavian Countries, Japan, etc. The Conference was sitting in May-June, 1899 and elaborated the convention on the peaceful settlement of international conflicts, on the laws and customs of the ground war, confirmed the decisions of the convention of 1864 about the rules and the conduct of a naval war, on prisoners of war, sick and the wounded. 
They say that the Sovereign is afraid to lose the capital of the Imperial family in case of discord with Britain, i.e., by this loan Queen Victoria has put him in her pocket.

In friendly France they say about incomprehensible policy of our government: L'Empereur de Russie voudrait bien venir en aide aus braves Boers, mais le pauvre homme ne sait pas comment s'y prendre! [The Russian Emperor would be glad greatly to come to the aid of the brave Boers, but the poor man does not know how to do it!]

As to our country, the spread of the news of that loan given to Britain from the Russian money, the feelings of disapproval towards the young Empress are spreading far and wide and turning into open hostility...

The trip of the Sovereign and the Empress to Moscow on the Easter's Eve is explained by the public opinion as a wish of the Sovereign to possibly smooth the impression created by rumours about the sympathy and loyalty of the Empress to the British interests.

It was hoped, that the demonstrative visits to churches and monasteries and the execution of rituals of the Orthodox church in the centre of Russia and in the ancient capital would convince the people and the society that the Empress was not an English woman, but a Russian; but this goal will hardly be achieved." 19

Britain, nevertheless, was rather worried of possible Russian and French actions. Thus, the Russian military agent to the British forces in South Africa Colonel P.A. Stakhovich ${ }^{20}$ on his way to South Africa stressed in his dispatch from London the vulnerability of the British positions after the outbreak of the War.

“...We'll depart from here on Saturday, November 6 to Glasgow and we'll sail off the next day on board of a troop carrier...

I deem it necessary to mention that the public opinion and newspapers here are looking forward to unfriendly and decisive actions on the part of our country as well as on the part of France with great nervousness. The Persian Gulf is pointed to as a scene of such possible actions.

It is due only to that fact that the mobilisation of the Reserve [Naval] Squadron has started here." 21

General V.V. von Vaal. "Zapiski 1900 g. Aprel - iun'. Otdel rukopisei Gosudarstvennoi publichnoi biblioteki. fond 127,6 , tetrad' 3, listy 52-55. [In Russian][General V.V. fon Vaal. "Notes in May-June 1900". The Manuscripí Department of the State Public Library. Fund 127, 6, book 3, pp. 52-55] Quoted in: Rossiya i Africa. Documenty i Materialy, p.154.

Colonel Pavel Alexandrovich Stakhovich, (1862-193?) later Lieutenant General. Took very active part in the Russo-Japanese War (1904-1905) and the First World War (1914-1918). After Bolsheviks' revolution (1917) he immigrated to Western Europe.

Doneseniya Generalnogo shtaba polkovnika Stakhovicha...Donesenie I ot .27 oktyabrya 1899 iz Londona. 2. St-Petersburg, 1900. [in Russian] [Dispatches of 
Lieutenant Colonel Y. Miller, Russian military agent in Brussels and Hague, presented a vision of the events from the side of those who sympathised with Boers: ${ }^{22}$

"The Dutch newspapers are giving the following distribution of the 10 million pounds requested by the [British] Parliament for War needs.

About one half of that sum will be expenditure, for troop shipments to the theatre of war the operations, purchases of horses, mules and others means of transportation will cost 1400000 pounds, the shipment by sea and by land proper will cost 3500000 pounds; the increase in salaries of the expeditionary personnel will cost 1000000 pounds, not to count those of the militia which will cost 250000 pounds; uniforms (the main supplier is Manchester) - 650 000 pounds; the medical service -50000 pounds",23.

In November 1899 the Russian military agent in Britain conveyed some preliminary conclusions about the Boer's tactics, unexpected by many.

"The note of the Russian agent in London Colonel of General Staff, Yermolov about military actions in South Africa. London. November 29, 1899.

The tactical position of the British forces, judging from the combats that had occurred is far from favourable.

The Boers have no bayonets. The Boers are horsemen, they are excellent shots, they are mounted infantry without bayonets. Lacking cold arms, the Boers don't accept or don't stand bayonet or sword charges. Their tactics is fast, mobile manoeuvre, heavy marksman's fire delivered from covered positions, actions on the communications lines of the British and the retreat in case of bayonet charges of the latter. (In case of such charges they mount on horses and withdraw).

Colonel of General Staff Stakhovich on 27 October 1899 from London, p.2]. St.Petersburg, 1900.

22 Lieutenant-Colonel Yevgeny Miller, later Lieutenant General (1867-1939). In 18981907 - The Russian Military Agent in Belgium, Holland and Italy. In 1912-1914 the Head of Staff in Moscow Military District. During the First World War - Corps Commander. In 1917 he was appointed the Russian Military Agent in Italy. Took very energetic part in the Russian Civil War (1917-1922). In 1919 - The Commander-in Chief of the Northern Front. After the White Army defeats he immigrated to France where in 1930 became the head of the Russian Military Alliance, the organisation of the White Army in exile. In September 1937 he was kidnapped by the agents of People's Commissariat of Internal Affairs (this Governmental organisation after 1954 was named KGB) from Paris. (The reason for such action was his intention to support military the Fascist Germany in the approaching war between the USSR and Germany). Miller was shot dead in May 11, 1939.

23 Doneseniya voennogo agenta v Brussele i Gaage Generalnogo shtaba polkovnika Millera V, ot. 21 oktyabrya 1899 g. iz Brusselya, s. 11. [in Russian][Dispatches by Russian military agent in Brussels and Hague Colonel Miller, on 21 October. p. 11]. St-Petersbuerg, 1900. These figures testify that the Great Britain since the very outbreak of the war didn't pay due attention to medical facilities for the troops dispatched for faraway mission, which resulted in great number of casualties among the British personnel. 
Such Boer tactics seems extremely disadvantageous for heavy, lowmanoeuvrable [British] troops simply because it is very difficult for immovable British troops to chase down the Boers, or to cut up their forces, let alone the Britush torces have very small number of cavalry (only 6300 horsemen against the whole Boer army) and the British cavalry is not capable at all of fast manoeuvring.

The infantry can deliver fire on the Boers, but to take them, to crush them is extremely difficult. Such enemy's tactical peculiarities put the British in an undoubtedly difficult tactical position. The British press absolutely does not understand that: it sees victories in every Boer retreat and in their disappearance from the occupied positions.

But there are no victories of any kind: the Boers simply do not wish to sacrifice the people of their numerically limited army and they withdraw, disappear, and then appear on other positions.

These are their tactics. These considerations are evidently confirmed by comparatively small casualties among the Boer forces, and on the contrary, comparatively high lose of the British, especially in prisoners of war; the Boers probably outride them, surround and take prisoners.

The Boer army almost has not suffered loses and is able to offer staunch resistance to the advancing enemy, defending every inch of their territory, retreating, enticing, changing the positions, concentrating near advantageous defence centres, affecting the internal lines and disturbing fragile British communications.

All that gives grounds to think that the war will be protracted, bloody and rather difficult and hard for the British.

In other words, it is very possible that the British meet serious difficulties before they reach Pretoria, and, perhaps, will suffer setbacks and defeats, or simply will not succeed in their military and political task." 24

Some news sent from South Africa by the Russian military agent on the British side Colonel Stakhovich are fairly exact remarks on the general state of affairs.

"1) In the time of peace the British Army does not make up large tactical units; in the time of war it was supposed to do so, but the situation interfered with that: reinforcements were urgently needed, and all that was at hand was taken and sent to the places where the demands were higher.

Due to that many units got mixed and a new improvised organisation appeared. That is hardly good.

2) Initially it was supposed that the forces available would be enough to launch a serious offensive on Bloemfontein and Pretoria.

But the circumstances of war required a mass of troops on both flanks and there was practically nothing left for the main attack. As a result reinforcements were needed. 
Until these forces arrive the situation in the centre [of the British position] is not secured.

3) In general the lack of cavalry is noted, and the one available is mostly doomed to complete inaction: the horses after a sea voyage are not suited for military actions for the first couple of weeks.

That is why we have practically no news about the actions of the [British] cavalry.

4) All admire Boers' actions very much and say they are using their defences brilliantly and skilfully.

I consider their actions unsatisfactory; suppose, they are not suited for offensive operations for many reasons, but one should not forget that it's impossible to achieve satisfactory results by passive actions. Once they started the war, they should have risked taking more decisive and active actions (at least actions against communication lines); they should have better and broader use their force superiority and the enemy's unpreparedness.

Now the time is lost (or almost lost)., 25

For the first time for many decades the Great Britain suffered very substantial military humiliations that gave a pretext for open criticisms of the leadership from the part of the British.

“... London, 1899.

Copy of the note by Colonel Yermolov.

...Among the military, reproaches and blaming are heard... mainly:

1. For the weakness of the field artillery.

2. For the absence of the position artillery.

3. For the arrival of the cavalry and the artillery and mortar batteries in the tail of Buller's corps.

4. For the dispatch of troops in packs by divisions.

5. For the absence of horses.

6. For the absence, at the theatre of war, of the combined army transport; there are no mules; no drivers; no saddles, there is no preliminary and carefully elaborated transport organisation, - it's a very hard circumstance for the Army, because it keeps the troops attached to very fragile, overloaded railroads and prevents their manoeuvre in the field.

7. And lastly for all the strategic mistakes which swallowed such a great mass of troops in the Natal's deadlock, where there are not even ships to carry, the troops back to the normal offensive lines." 26

From South Africa Colonel Stakhovich also reported very interesting data about the situation in the British Army. 
"I had a talk ... with [British]... artillery officers. One young officer of mounted artillery, who had been wounded near Magesfontein, asked me about our [Russian] Army, admired everything I told him, and exclaimed bitterly in the presence of others: 'That is not like with us: everything is wrong with us: the manning and armament; the generals don't know their troops and see them for the first time at the battlefield; different arms and services also don't know one other and are unable to co-operate. Various parliamentarians who are ignorant in military matters control us: we are in neglect; they are doing nothing for us, and they dare reproach us that we can't fight.'

Another officer from the Scots Grey complained that the generals are not capable to use the cavalry; for example on the third day after their regiment's arrival, when all the horses were in a terrible state, they were ordered to carry out a long march which caused special suffering to the horses.

The third officer, a battery commander, said that according to initial disposition his battery was not detailed for departure to South Africa; then during the mobilisation of other batteries almost all horses were taken from him, as well as all the best gun layers and fire-workers, all officers, safe for but one captain, and finally he was himself dispatched here [to South Africa] too. Later his battery was mobilised as well. It is due to arrive here on February 14 [1900]. 'I received the order to meet it and assume command.

Imagine how good it would be - it was mobilised under the command of one captain, all the officers are newly appointed and of course inexperienced and there is no single one with a service record, only the worst men and rig-rags remained, the arrived reservists are all of course good for nothing, the majority of them are so old that don't know the canons of new design; the horses have not been adapted to service, what a joy to assume command of such a battery! Of course, one has to start with the alphabet, to teach them elementary things. But what will happen if in several days there should be a combat engagement?' The mentioning of the troops from the colony provoked a storm of indignation. The general opinion was that they are spongers and misfits and courting them is the policy of the civilian minister. Meanwhile the commanders know their real price because employ them to secure communication lines in the rear only. An artillery man added: "If we, the regular troops, were paid 5 shilling a day per private we would get better men than those." 27

Another Colonel Stakhovich's report, which was dispatched from Bloemfontein, capital of the Orange Free State, after it had fallen into British hands, is noteworthy:

“...While analysing operations from February 16 to 27 which ended up in so successfully for the British, we should recognise the expediency of measures taken by the Commander-in-Chief.

During the evening of [February] the 15th [1900] the news was received that the siege of Kimberly had been lifted and it became evident that Cronje with the majority of his forces is retreating to the East. 
Several energetic measures are taken to block the route of the retreat; the troops had to assume serious strain, and the units, especially the cavalry, were making forced marches.

Meanwhile the situation in the evening of the 15 th as received by Commanderin-Chief was not favourable for taking such an energetic decision. It was exactly at that moment that the news came: substantial forces of the enemy appeared in the rear and captured the whole of the food supply transport; while the [British] troops had only three days individual and immediate supply rations available. Knowing that one day delay would give Cronje an opportunity to escape, Lord Roberts decides to advance without hesitation; he cuts the troops ration to a half, abandons his communication line to Enslin (calling back the last unit from Waterfall to Jacobsdal and risking even to give access for the Boers to the railroad) calculating on opening the road to his Modder River Camp on the following day where a large stock of food and means of transportation were available.

The surrounding of the enemy, who stayed at the Paardeberg laager was made on February 18 energetically and fast; as to the attack of this laager on that day, it should be considered unwarranted and unsuccessful.

The slow pace of the following actions can be justified; it was not necessary to capture the laager until the stock of food in Paardeberg was replenished to provide for non-stop move to Bloemfontein.

Cronje's actions during the same period of time were often wrong. His main and unforgivable mistake was his stop in Paardeberg. It seems to me doubtful that he could have retreated further, when there was no more than one cavalry brigade on his flank (almost in the rear), hardly capable (especially if we take into account its poor condition, but Cronje could not know about it) of blocking his further march. At last he could have sacrificed transport and the several heaviest canons and could have retreated freely, which he should have known.

His stop could have been justified in one case only: if he decided to sacrifice his detachment to save time at any cost for the Boers to concentrate for the defence of Bloemfontein. But there was no intention at all to defend the city. It means that the stop was a serious mistake.

After he had taken the decision to stop, he chose a very wrong place, his laager was situated in a very low place and was surrounded by commanding hills at a range of a good cannon shot.

The Boers waged passive defence of the laager well as usual when the covered defence was on the agenda. But one can't help but condemn the fact, that they did not try a single sortie (because of the extension of the line of siege and bad combat outpost service of the enemy they could have inflicted on him several local defeats) and did not try to break through even once.

It seems to me that should they wished to break through in the Eastward direction (abandoning the transport, of course) on February 19, 20 or on 21st, they would have undoubtedly succeeded and I think even without loses. The whole situation was favourable: Kitchener's height was in their control, while the British on the Eastern section of the line had only two weak battalions which had suffered heavy loses on February 18; and the [British] cavalry 
detachments were not very close and they were not capable for energetic actions.

After [February] 21st when the British captured Kitchener's height and the Eastern part was already guarded by the whole 14-th brigade with artillery, and not by two battalions, a breakthrough in that direction at daytime could not have been made otherwise than at a cost of substantial losses.

But at nights by small groups and going in different directions thanks to their wonderful knowledge of the terrain they could freely abandon the laager until the last day of the siege.

They did not attempt to do anything of that, but surrendered together with the great number of shells and cartridges (as I was told they had not much food, but enough for several days more), and bringing shame on the Majuba day [February 27], so dear to every Boer.

If, having decided to surrender, they had had fired all the shells and cartridges during the last day they would have inflicted some harm on the enemy and would have avoided the reproach that they had surrendered with arms ready for actions in their hands.

As I heard, the Boers were absolutely convinced that the British had bribed Cronje. Though I don't believe it, but I can't but admit that some of his actions arise suspicion. One can't but get surprised the day selected by him for surrender, though the circumstances had not forced him to surrender on that very day; the frequent exchange of truce envoys seems strange too, let alone that there was no ürgent need for such actions... And it was strange that Cronje agreed to the exchange of war prisoners as by this action he disclosed his laager's defence outlay and combat facilities."

\section{The analysis of the last stage of operations}

During the last period of operations it is necessary to note:

1. The absence of serious enemy resistance: after Cronje's surrender, almost 30 thousand-strong corps led by Lord Roberts was facing not more than 4 thousand Boers. The terrain, where the offensive was taking place, was not favourable to staunch defence, because all the positions could be easily outflanked.

2. The only difficulty for the offensive consisted in the food supplies for the troops because there was neither food on the spot, nor railway suited for its convenient delivery.

3. As it was mentioned above, the army's food supplies were provided in an excellent way and all the necessary measures had been thought over beforehand and brought to implementation on time. On their part the Boers did not do anything to prevent the success of the operation; in this respect they neither destroyed the country's means nor carry them away, but left in full possession of the advancing enemy. Save but the only attack on transport near Waterfall, they did not either threaten the enemy communication lines, in any way, nor prevent the free movement of his transports. 
It is hard to believe that with the communications line being as long as 170 verstas $^{28}$ and the population being undoubtedly hostile to the British marching through the country, the telegraph links with the rear have not been disturbed a single time. Such enemy actions enable the British to spend very few forces for the protection of the rear." 29

We can extract some interesting information from the memoirs of Yevgeny Feodorovich Augustus, ${ }^{30}$ a Russian volunteer, career infantry officer, who fought on the Boer side and whose memoirs supplement, to a certain extent, the abovementioned dispatches by Colonel Stakhovich:
"The first activity of the far-sighted Field Marshal [Roberts] was the formation of numerous regiments of mounted infantry as an arm of force the most adapted to military actions against the Boers.

The horsemen of the mounted infantry were recruited among the local settlers, among the farmers as well as town dwellers of South Africa. Attracted by high salaries amounting to $10-15 \mathrm{~d}$ a day and a perspective of unpunishable marauding and looting, many homeless seekers of adventure and gold miners of Johannesburg, who had fled to Cape Town upon declaration of war and remained jobless, were enlisting in the newly formed regiments. Such subjects manned regiments named Imperial Horse, South African Light Horse, Brabant Horsemen, Remington Horse, Roberts Horse, Prince Albert's Horse and others. Being excellent connoisseurs of the local environment and having a habit to hard life of trumps, courageous scouts and gallant riders, those horsemen did serious service to the British Army, though as any freebooters, they hardly obeyed the military discipline and terrified the peaceful population by looting and robbing.

'After Brabant Horses, the locusts have nothing to do' as the peaceful settlers of the Cape Colony and the Free State used to say about them later.

Roberts' actions showed how one should learn from the lessons of war, and that the first pledge for the successful accomplishment of the operation concept is the reasonable elaboration of preparatory measures.

Though the very fact of taking limited in strength Boer militia prisoners by 35000 regular troops can't be considered an outstanding feat, nevertheless the British Army displayed such energy and endurance in standing the privation during the forced marches through the sandy and waterless desert, that

One versta is $1.0668 \mathrm{~km}$.

Doneseniya Generalnogo Shtaba polkovnika Stakhovicha. XIX ot.10 aprelya $1900 \mathrm{~g}$. iz g. Blomfonteina, [on 10 April 1900 from Blomfontein], St-Petersburg, 1900, pp. 164].

Yevgeny Fiodorovich Augustus, an infantry officer, Russian volunteer, served in the Krugersdorp commando, in the Russian Detachment and in the Johannesburg Police commando. He was wounded and taken prisoner by the British forces in June 1900 and was released soon after he had pledged a word of honour not to fight on the Boer side again. He wrote very interesting and detailed memoirs about his participation in the Anglo-Boer War. Later he took part in the Russo-Japanese War of 1904-1905. In 1911 Yevgeny Augustus had a rank of Captain 2nd Rate (later he was probably killed in the First World War.) 
Cronje's capitulation will be a glorious page in the history of the British Arms forever." 31

The Russian military agent on the Boer side, Lieutenant-Colonel V.I. Romeiko-Gurko, ${ }^{32}$ was sending interesting information about the events at the theatre of operations as a direct witness. For example, in March 1900 he sent a message about one of the Boer defeats that followed Cronje's surrender. And he explained the reasons for their failures:

"After the surrender of General Cronje's detachment, the British troops after more than a week's impasse resumed the offensive movement again on March 7.

At the time when the bulk of the infantry moved along both banks of the Modder River the cavalry and most part of the mounted infantry took use of the undefended break on the left flank of the allies, and moved through it, forcing the Transvaler troops on the left flank to retreat to the South.

In spite of the evident intention of that cavalry column to repeat the manoeuvre, which was successful in surrounding Cronje, General De Wet intended to stay at his positions and to repeal the attack of the British infantry.

But the troops subordinate to him evidently had another opinion.

In the Transvaal troops the men are partly following the deeply inrooted principle, that in the battle "each man is his own officer", and, partly knowing from the practice that during the battle the orders of the superiors seldom reach them, consider themselves right to decide on their own when it is time to leave the position and to start a retreat... The same in this case; hardly an hour passed after the minute when the first horsemen had left the trenches, as they were completely abandoned... Giving himself acquit of full inability to stop his men, General de Wet decided to move to the nearest chain of hills which presented by itself a good rear position and tried to stop his troops there and to organise the defence.

He succeeded to some extend. The rifle fire opened by his men at the line formations of the British infantry in the centre stopped them for some time and enabled the Transvalers to save their transport. But the Transvaal troops did not stay long on that position either and resumed their retreat towards the town of Brandfort because the decision had been made to surrender the capital of the Orange Free State without battle. The reasons why the allied troops did not want to offer serious resistance to the enemy advance, lie equally in the

Augustus Evgeny Fiodorovich. Vospominaniya uchastnika anglo-burskoi voiny. Varshabsky voenny zhurnal, [In Russian] [Avgustus, Yevgeny Fiodorovich. Memoirs of a Participant in the Anglo-Boer War. The Warsaw Military Magazine] Warsaw, 1901, 7, pp. 644-645.

32 Lieutenant Colonel, later Army General Vladimir Iosifovich Romeiko-Gurko (Gurko) (1864-1937). Took part in the Russo-Japanese War 1904-1905. During the First World War - the Army Commander. From October 1916 to February 1917 - acting Head of the General Staff. After Bolshevik revolution he refused to command the Northern Front of the White Army during the Civil War in Russia and immigrated to Western Europe. Wrote several books of memoirs (such as Tsar and Tsarina). Died in Rome in 1937. 
disadvantageous and especially in the extremely extended position occupied by them as in moral consequences of the recent failures.

The extreme extension of the occupied positions and their favour, the cordon system of troops deployment are the consequences of the desire of detachment chiefs to meet the enemy ten times stronger then they are on every possible route of his offensive.

It seems that the allied troops, always smaller in numbers than the enemy, would have substituted it by development of their mobility, by using the advantage that all of them are mounted but this is what they are hardly capable of doing.

On the other hand the mobility of these Transvaal 'commandos' is hampered by their heavy oxen transport, which they greatly dislike to abandon."33

By April 1900, the British enthusiasm about the near victory over the Afrikaners faded somehow. Colonel Yermolov, pointed in April 1900 at some political reasons to that in his dispatch from London:

"Certain anxieties and doubts about the possibly of ending the war soon again began to express themselves here. They began to think that the successes of the British troops had not been so decisive and that the conquest of the Orange Free State is far from being as complete as they thought.

They say here that there is no doubt that the British will have the upper hand in the end, but nevertheless, the war will not come to an end earlier than by November. And after it there will be hard and dangerous occupation which will require no less than 50000 men.

Though it is beyond doubt that Britain wishes to win and does everything at any cost for annexation of the enemy territories, yet here they treat every news from the theatre of war very nervously; as soon as good news for the British come, their mood going up by leaps and bounds, they start boasting about their successes and victories, in fact "discount" these successes i.e. Roberts promises to lift the siege of Mafeking; to offer dinner to foreign military attaches in Pretoria and so on. But as soon as the things are getting worse, anxiety and lower spirit are becoming evident among them. Such correlation of mood to the reverses of war is not, seemingly, typical of the English character. But that is easy to explain - that is a sign of their military weakness, they have no confidence either in the army, or in the generals, or in the War Office. Besides there is another curious circumstance that I should mention: 'The Boers are extremely influencing their imagination'. Their mobility, patriotism, marksmanship, strange tactics, Christian treatment of the wounded, and lastly, the very war events, stories about the Boers, the letters of the soldiers from the theatre of war, all that gives almost an air of a legend to the Boers and all that influences the British in the sense that, sometimes, they are just afraid of the Boers and that is why they are getting nervous at setbacks. Besides there are other circumstances; the war revealed a great number of

Doneseniya Generalnogo shtaba podpolkovnika Romeiko-Gurko [In Russian] [Dispatches of Lieutenant-Colonel Romeiko-Gurko]. St. Petersburg, 1900. IV February 22. 1900 on the board of steamer "The Mexican" from Cape Town to Lorenco-Markes, pp. 3-5. 
shortcomings in the miltilitary organisationtion, many mistakes, drawbacks, lack of preparedness, a chaos in all the British military affairs. They give themselves good account of it here it and the officers who stayed here are saying "We wish this war end victoriously, the sooner the better in order to start full reorganisation and strengthening of the army and lift it to the same level of perfection as where our Navy is. What our fate would have been if a continental army were our enemy?"

All that are the sights of military weakness and it impossible to overstress the fact that British Armed Forces never have been so weak and probably will never be so weak as nowadays; now all is weak - Britain, the colonies and India.

But on the day when the war ends, the decisive measures will be taken to remove the noticed deficiencies and in 2-3 years Britain, the colonies and India will gain significant strength in military sense." 34

In his book published in 1901 after his return home, Romeiko-Gurko, promoted by that time to the rank of Colonel, came to a conclusion that it was not only due to the hard climate and the mountainous terrain that the war turned to be so protracted:

"If thus we see that Britain is still unable to suppress the South African Republics' armed resistance, then that is partly explained by the low fighting capacity of the British Arms Forces and by the lack of talented commanders among them because up to now not a single genuinely outstanding officer stood out on the British side. And partly, it is confirmed once again that it is difficult to fight a people's war; even more skilled warriors than the British were not in their power to deal with it." 35

On the other hand, Second Lieutenant Yevgeny Augustus described the attitude of the Russian volunteer to the disorder prevailing in the Boer laagers which was one of the reasons for Afrikaners' defeat.

“...We tested, endured and experienced much during [our] stay in trenches above the muddy Tugela. We recognised that neither republican valour nor self-resigned courage, nor bravery of certain individuals can't expiate the lack of military organisation and the absence of military discipline."36

In his memoirs he described in sufficient detail and, at the same time in a digestible form the causes for the initial British military defeats and for the victories of the Boers, who were defending their positions in the mountainous area:

Doneseniya voennogo agenta v Londone Generalnogo Shtaba polkovnika Yermolova [in Russian] [Dispatches of the Russian military agent in London Colonel Yermolov], St. Petersburg, 1990, LVIII. April 5, 1900.From London. pp. 1-3.

Voina Anglii s Yuzhno-Afrikanskimi Respublikami (Otchet Komandirovannogo po Vysochaishemu Poveleniyu Generalnogo Shtaba Polkovnika V.I. Romeiko-Gurko). [In Russian] [The War of the Britain with the South African Republics. A Report by Colonel of the General Staff V.I. Romeiko-Gurko, dispatched there on His Majesty's orders]. St.Petersburg, 1901, p. 261-262.

Augustus Evgeny Fiodorovich. Vospominaniya. Varshavsky voenny zhurnal, 1901, 9, p.889. 
"By the end of the first period of war the Boers had the upper hand everywhere.

At Tugela all the efforts by Buller were laid waste. In the Cape Colony General Gatacre trying to finish off with the Boers by a night attack, was ambushed and suffered a substantial defeat at Stormberg. Things stood no better with the dashing athlete [General] French. He was defeated several times by De Wet, one of the best Boer commanders.

And [General] Methuen decided to crash the stubborn enemy by front attack according to the rules of boxing and lost in the encounter of November 27 and December 11 [1899] the cream of the British Army - the Guards Brigade and the Scotch Brigade.

The British press justified the chain of these disgraceful defeats by alleging that these horrible losses suffered by the British are the result of the disastrous Boer fire that caused complete disturbance in the ranks of the attacking troops.

But should we pay attention to the statistics we shall see that it was not the high percentage of loses that caused the defeats but the lack of combat training and genuine soldier's spirit.

Our losses during the campaign of $1877 / 1878$ [the Russian-Turkish War] sometimes reached 40-90\% (at Plevna, Gorny Dubnyak. Ene-Zara); German regiments at Gravelot, Saint-Privat, Vert, [during the Prusso-French War] lost more than $15-45 \%$, of their strength, and the British? The bloodiest days at Spioenskop, Maggersfontein, Colenso cost the British on the average no more than $9 \%$ in dead and wounded.

These demonstrative figures are speaking for themselves and it is sad to think that a false impression about the power of the Great Britain was pressing on Europe like a nightmare and brought Russia to the Berlin Congress. ${ }^{37}$

And now a small, hitherto almost unknown people courageously faced the challenge of the powerful "Ruler of the Seas" in front of whom several years before France had retreated at Fashoda; and infected several disgraceful defeats.

But the Boers failed to take advantage of their position. There was not almost a single instance [on their part] of taking a persistent offensive in order to pursue stubbornly and then destroy and crush the enemy retreating after his attack.

And all that led to the situation when the British thanks to the Boers inactivity gained enough time, corrected their mistakes and taking advantage of the

The Congress of Berlin (1878) was called for the revision the conditions of SanStefano Peace Treaty that concluded the Russo-Turkish War (1877-1878). Russia made concessions, being afraid of a possible war of major European powers against her; the Russian authorities didn't even suspect that the military effectiveness of the British ground forces was very low. 
disproportion between the [conflicting] forces crashed the enemy in the unequal struggle." 38

The British took prisoner many foreign volunteers. Some of them were released and received permission to come back home, but others spent several years in concentration camps up to the end of the war and even afterwards. Captain of the 2nd Rate Alexander Shulzhenko, ${ }^{39}$ a Russian military engineer, was among them. In his personal letter from a concentration camp in India on October 1, 1901 he confirmed the widespread public opinion about the striking weakness of the British Ground Troops:

"God Damn the British: I have not seen more foolish persons in military matters. If the Boers had a little bit more of order and information, they would have thrown them out of South Africa... During this war the British troops did not get any experience, moreover they got spoiled completely." 40

However, above mentioned Russian volunteer Yevgeny Avgustus expressed a much more favourable opinion of the British Army:

"Instead of front attacks practised by Methuen and Buller, almost exclusively by dense rifle lines supported by close order infantry columns, Commander-inChief Roberts used new tactics. Taking into account the enemy peculiarities, who almost always was holding strong position hardly accessible from the front, Roberts vested purely demonstrative role on the infantry and artillery; as their fire attracted all the attention of the enemy, but the main task was to be carried out by the cavalry and by the new arm of the mounted infantry, which moved far forwards and had to envelop the flanks and the rear of the Boers.

This tactics in most cases was successful thanks to the British manpower superiority and the dreadful force of the artillery fire that enabled them to assign the coverage of the whole space instead of hitting individual targets. The results were not always proportional to the number of spent shells but the effect was always convincing.

There were many censures against the British Army; many columnists mocked it in newspapers and humour magazines, but this Army has a soldier's spirit and Waterloo, Balaklava, Luknow and Ladysmith all prove it.

I know the British army not only by cartoons in the Journal amusant or Budilnik ["The Alarm-clock" - a Russian humour journal], I felt it by my own ribs - what means to fight with the regular Tommy Atkins.

Lying in the trenches, attached to the rifle butt I sometimes unwittingly forgot to hold 'the direct sight line' while peering out at the pale faces of the soldiers who were slowly climbing up the steep slope of the mountain, where from the

Augustus Evgeny Fiodorovich. Vospominaniya uchastnica anglo-burskoi voiny. [In Russian] [Augustus, Evgeny Fiodorovich. Memoirs of a Participant in the AngloBoer War]. Warsaw, 1902, pp. 122-124.

This Russian officer was released only in July 1902 and all the time spent by the Captain 2nd Rate Alexander Shulzhenko on the battlefield (15 months) and in the concentration camp (17 months and 19 days) was included in his active service and a financial allowance was partly paid off to him as well (later he was probably killed in the Russo-Japanese War of 1904-1905).

AVPRI. Fund 151, document 2123 (a), p. 21. 
invisible enemy under the cover of stones was pouring torrents of fire upon them. They were going on and on with their advance, with no Generals riding in front of them, no banners waving over them, in their unstoppable movement towards the sure death. That was at the Tugela, on the bloody day when Peter's Hill was stormed.

I heard the Boers asked a Scot prisoner: "How long are you going to hold on in Ladysmith? The soldier, exhausted by hunger and hardships, answered proudly: "So long as we have cartridges!"

I saw how a platoon of Dublin Fusiliers taken by surprise by [Boer] mounted patrols was fighting off with bayonets and butts, reluctant to think of surrender. A wounded officer, bleeding, shouted in a hoarse voice to the soldiers: "Fix bayonets! No surrender! (An episode from the Free State campaign). Out of 12 men only two surrendered to us..."

The after-effect of the war was a subject of interest for Russian representatives later as well. Russian diplomat Poklevsky-Kozell wrote from London September 9, 1903, more than a year after the Peace Treaty between the Great Britain and the Boer Republics had been signed on May 31, 1902. The letter contains some conclusions made by the British about the past war.

"The dead season in the political life of the country after the closing of the parliamentary session was interrupted some days before by the publication of the Report of the Royal Commission about the South African War.

... The results obtained and published now are really astonishing. It came out to be that there were no plans of the campaign and the generals dispatched one by one to command the army received neither instructions nor directives.

The Head Quarters, improvised only after the declaration of the war was functioning extremely badly. There were no field uniforms, saddles, and good high boots. The rifles were badly adjusted and a great number of cartridges in stock were unfit. The reserve of cavalry swords, albeit of extremely bad quality, was only 80 . In the commission's opinion, nothing at all was thought over in advance.

Under such circumstances it is hard for me to believe that the Government of Great Britain was trying intentionally to provoke the South African Republics to start the war.

I would sooner agree with the opinion that it did not believe in the possibility of war and hoped for President Kruger's pliability, and his ultimatum was a great surprise.

The newspapers put the blame of irrelevance and incapability on persons who were responsible for the lack of preparedness of the Army, and especially blame the Marquis of Lansdowne, who was War Minister at the outbreak of the War. 